\title{
Effects of GLP-1 and Incretin-Based Therapies on Gastrointestinal Motor Function
}

\author{
Chinmay S. Marathe, ${ }^{1,2}$ Christopher K. Rayner, ${ }^{1,2}$ Karen L. Jones, ${ }^{1,2}$ and Michael Horowitz ${ }^{1,2}$ \\ ${ }^{1}$ Discipline of Medicine, Royal Adelaide Hospital, University of Adelaide, Adelaide SA 5000, Australia \\ ${ }^{2}$ Centre of Clinical Research Excellence in Nutritional Physiology, Interventions and Outcomes, University of Adelaide, \\ Adelaide SA 5000, Australia \\ Correspondence should be addressed to Christopher K. Rayner, chris.rayner@adelaide.edu.au
}

Received 2 February 2011; Revised 4 April 2011; Accepted 19 April 2011

Academic Editor: Matteo Monami

Copyright () 2011 Chinmay S. Marathe et al. This is an open access article distributed under the Creative Commons Attribution License, which permits unrestricted use, distribution, and reproduction in any medium, provided the original work is properly cited.

\begin{abstract}
Glucagon-like peptide 1 (GLP-1) is a hormone secreted predominantly by the distal small intestine and colon and released in response to enteral nutrient exposure. GLP-1-based therapies are now used widely in the management of type 2 diabetes and have the potential to be effective antiobesity agents. Although widely known as an incretin hormone, there is a growing body of evidence that GLP-1 also acts as an enterogastrone, with profound effects on the gastrointestinal motor system. Moreover, the effects of GLP-1 on gastrointestinal motility appear to be pivotal to its effect of reducing postprandial glycaemic excursions and may, potentially, represent the dominant mechanism. This review summarizes current knowledge of the enterogastrone properties of GLP-1, focusing on its effects on gut motility at physiological and pharmacological concentrations, and the motor actions of incretin-based therapies. While of potential importance, the inhibitory action of GLP-1 on gastric acid secretion is beyond the scope of this paper.
\end{abstract}

\section{Introduction}

A role for gastrointestinal peptides (or factors) in the maintenance of mammalian glucose homeostasis had been speculated for more than 100 years. The search for these gut peptides was stimulated initially by the discovery of secretin by Bayliss and Starling in 1902 [1] and advanced by the work of others [2-5] before it fell out of favour. It was revived subsequently by the observations, by Elrick et al. [6] and McIntyre et al. [7] in 1964, that an oral glucose load resulted in a much greater insulin response than an intravenous glucose load despite resulting in comparable blood glucose concentrations- the so-called "incretin effect" [8]. Glucagon-like peptide-1 (GLP-1) was discovered in the 1980s following sequencing of the proglucagon gene and was shown soon after that time to have fulfilled the physiological criteria for an "incretin" as specified by Creutzfeldt [9], that is, a hormone released from intestinal cells following a nutrient load, which leads to a glucose dependent insulin response. GLP-1 was the second incretin to be characterized after glucose-dependent insulinotropic polypeptide (GIP), which had been discovered a decade earlier.

GLP-1, however, does not fit as well as GIP within Creutzfeldt's incretin definition [10]. For example, in healthy subjects [11] and type 2 diabetic patients [12], postprandial (as opposed to fasting) levels of insulin and $\mathrm{C}$ peptide are decreased by exogenous GLP-1, rather than stimulated (Figure 1), and when the slowing of gastric emptying induced by GLP-1 is reversed by the prokinetic drug erythromycin, the glucose lowering effect is attenuated [13]. The properties of GLP-1 as an enterogastrone (i.e., a factor that slows gastric emptying and inhibits gastric acid secretion) have also been appreciated $[10,14,15]$. In fact, it has been suggested that the actions of GLP- 1 to slow gastric emptying, and thereby the entry of nutrients into the small intestine to delay their absorption, may outweigh its insulinotropic and glucagonostatic effects [16]. In contrast to GLP-1, GIP has little effect on gastric emptying [17]. If anything, there is some evidence that GIP may modestly accelerate emptying from the stomach [18]. 


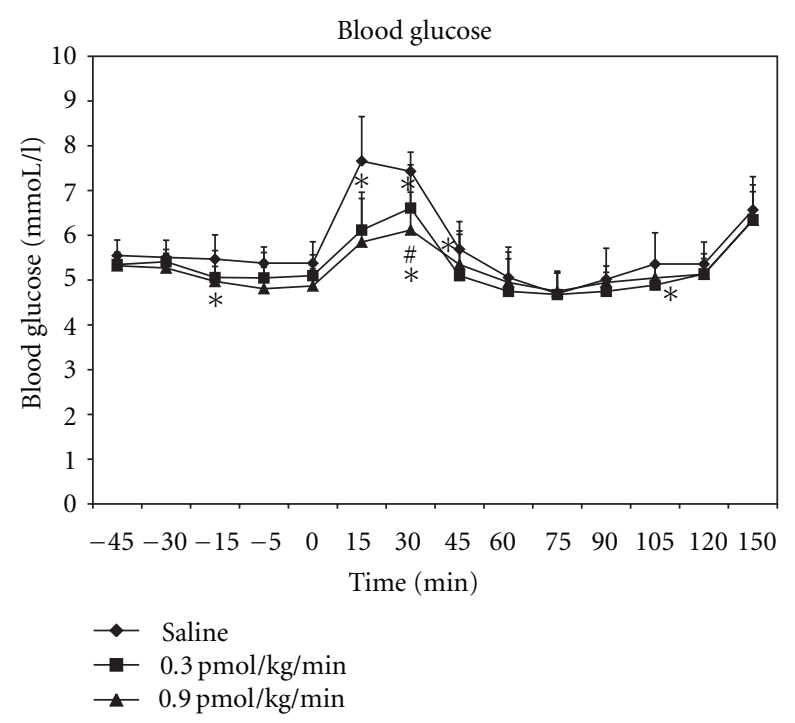

(a)

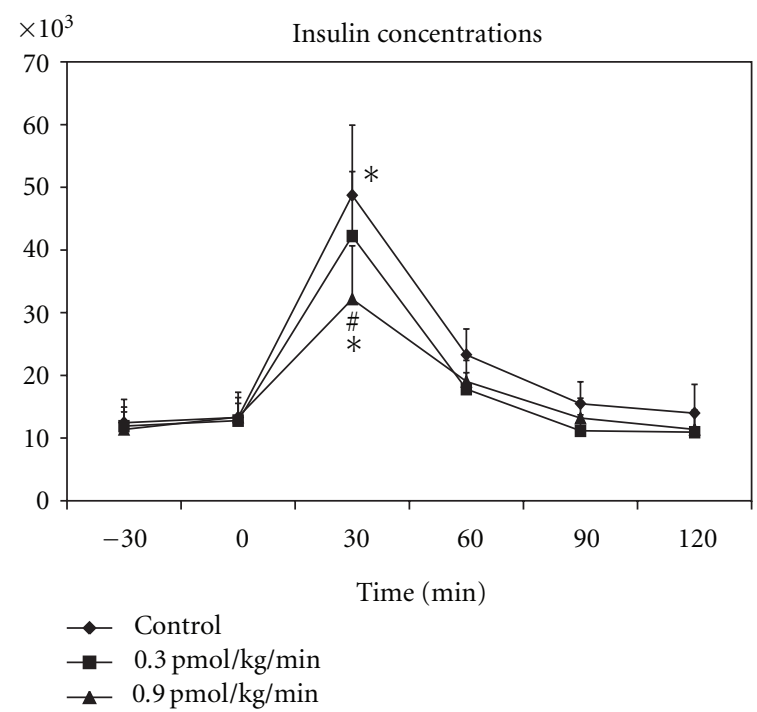

(b)

FIGURE 1: Blood glucose (a) and plasma insulin (b) concentrations during IV infusion of GLP-1, at 0.3 and $0.9 \mathrm{pmol} / \mathrm{kg} / \mathrm{minutes}$, or $0.9 \%$ saline, in 10 healthy humans. Data are means \pm SEM. ${ }^{*}$ GLP-1 0.3 and 0.9 versus saline: $P<.05 ;{ }^{\#}$ GLP-1 0.9 versus GLP-1 $0.3: P<.05$ (adapted from Little et al. 2006 [19], and used with permission from the publisher).

Some studies have reported reduced GLP-1 levels in type 2 diabetic patients [18, 20-24], although this has not been found uniformly to be the case $[25,26]$. It should be noted, however, that the efficacy of GLP-1-based therapy does not depend on a deficiency of endogenous peptide. Pharmacological "replacement" of GLP-1 is not straightforward owing to its very short half-life. GLP-1 is rapidly degraded by the enzyme dipeptidyl peptidase-4 (DPP-4), making it impractical for most clinical applications. This has provided the rationale for the development, and subsequent widespread use, of synthetic longer-acting analogues, such as exenatide and liraglutide (the two approved GLP-1 analogues), and DPP-4 inhibitors, like sitagliptin and vildagliptin, to improve glycaemic control in type 2 diabetic patients [27].

\section{The Physiology of Gastrointestinal Motility}

An overview of the physiology of gastrointestinal motility is useful in understanding the role and importance of GLP-1 in gut function. Gastric emptying, a highly regulated process of delivering chyme from the stomach to the small intestine, involves a complex interplay between the gastrointestinal smooth muscle, gastric pacemaker cell networks, the socalled interstitial cells of Cajal, and neurohormonal systems, particularly inhibitory feedback arising from the interaction of nutrients with the small intestine. Gastric and small intestinal motility is of predominutesantly two types: (a) peristaltic, in the interdigestive or fasted phase, and (b) segmented contractions in the fed, or postprandial state. Interdigestive motility is comprised of three sequential phases (phase I or quiescent, lasting $\sim 40$ minutesutes, phase II or intermittent, lasting $\sim 50$ minutesutes, and phase III or regular contractions, at about $3 /$ minutesute in the stomach and 10-12/minutesute in the small intestine, and lasting $\sim 5-$ 10 minutesutes) and is called the "migrating motor complex" (MMC) [28]. Transit of indigestible solid occurs mainly in late phase II and phase III of the MMC [29].

Once food (solid, liquid, or mixed) arrives in the stomach, the MMC is replaced by the postprandial motor pattern. For a solid or mixed meal, the proximal and distal parts of the stomach have different functions. The proximal stomach is concerned with the storage of food and accommodates the ingested meal by decreasing its tone [30, 31], enabling its volume to increase without a substantial increase in intragastric pressure $[31,32]$. In contrast, the distal portion of the stomach is concerned with the mixing and trituration of the meal. Antral contractions pulverise the digestible solid contents against the closed pylorus until they have achieved a size of 1-2 mm [33]. Phasic and tonic contractions localised to the pylorus play a major role in the regulation of gastric emptying so food particles are delivered to the duodenum following the opening of the pylorus, predominutesantly in a pulsatile manner [34]. The rate and pattern of gastric emptying are dependent on the composition (solid, semisolid, or liquid), osmolarity, caloric content, and size of the particles in the meal ingested. Liquids are preferentially transferred to the small intestine before solids. Nonnutrient liquids empty in an overall exponential pattern, while a more linear rate is observed as the nutrient and caloric content of the liquid meal increase. The presence of food in the stomach reduces appetite, and distension of the antrum, rather than the proximal stomach, appears to be more strongly associated with the perception of postprandial fullness [35], and suppression of subsequent energy intake [36].

The exposure of the small intestine to nutrients triggers a powerful inhibitory feedback to slow gastric emptying and 
small intestinal transit- the magnitude of this feedback is dependent on the type of nutrient [37], as well as both the length [38-40] and region [40-42] of small intestine exposed. GLP-1 and peptide YY (PYY), coexpressed with GLP-1 in the entero-endocrine L cells predominutesantly (but not exclusively) from the distal gut, appear to be potent mediators of the so-called "ileal brake" [43]. This small intestinal feedback mechanism results in highly regulated gastric emptying of nutrients, including carbohydrate, from the stomach to the small intestine at an overall rate of about 1 to $4 \mathrm{kcal} /$ minutes $[44,45]$. The release of GLP-1 from the small intestine is critically dependent on the carbohydrate load in both healthy subjects and type 2 diabetic patients [45-48]. When glucose is infused intraduodenally at the rate of $1 \mathrm{kcal} /$ minutes there is a minutesimal, and transient, release of GLP-1, whereas there is a substantial, and sustained, GLP-1 response to infusion at the rate of $4 \mathrm{kcal} /$ minutes [49], probably reflecting a greater length of small intestinal exposure [38]. Fat (mediated by free fatty acids), protein [50], and bile acids [51] are also potent stimuli of GLP-1 release from the L cells. For carbohydrate, it has been suggested that stimulation of intestinal "sweet taste" receptors triggers GLP-1 release [52], although in humans, the artificial sweetener, sucralose, does not induce GLP-1 secretion [53]. However, secretion of GLP-1 in response to sucrose is increased when malabsorption is induced by the $\alpha$-glucosidase inhibitor, acarbose, presumably due to exposure of the L cell-bearing distal gut to larger amounts of carbohydrate [54].

The terminutesal aspect of the gastrointestinal tract, the colon, is characterized by the presence of haustra (formed by nonpropagated phasic contractions), which compartmentalise the luminutesal compartment and favour stool formation by water and electrolyte absorption. Colonic motility is discontinuous, and mostly slow, which ensures prolonged retention of contents, though occasionally rapid activity allows large amounts of residue to be transferred across the colon within seconds. Expulsion of contents is regulated by the ano-rectum.

\section{The Interrelationship of Gastric Emptying with Postprandial Glycaemia}

Postprandial hyperglycaemia is being increasingly recognised as an independent predictor of cardiovascular mortality in both diabetic and nondiabetic populations $[55,56]$. The rate of gastric emptying influences postprandial glycaemic excursions and vice versa: a situation comparable to the "chicken and egg" relationship [57]. Gastric emptying is a major determinutesant of postprandial glycaemic excursions in healthy subjects [45] as well as type 1 and type 2 diabetic patients [46] so that slower gastric emptying is associated with reduction in blood glucose, especially in the first hour after ingestion of a meal [58, 59] (Figure 2). Conversely, gastrointestinal motor function is highly sensitive to changes in the glycaemic state [57]. For example, in both type 1 [60] and type 2 diabetic patients [61], an increase in postprandial blood glucose levels is associated with proportional slowing

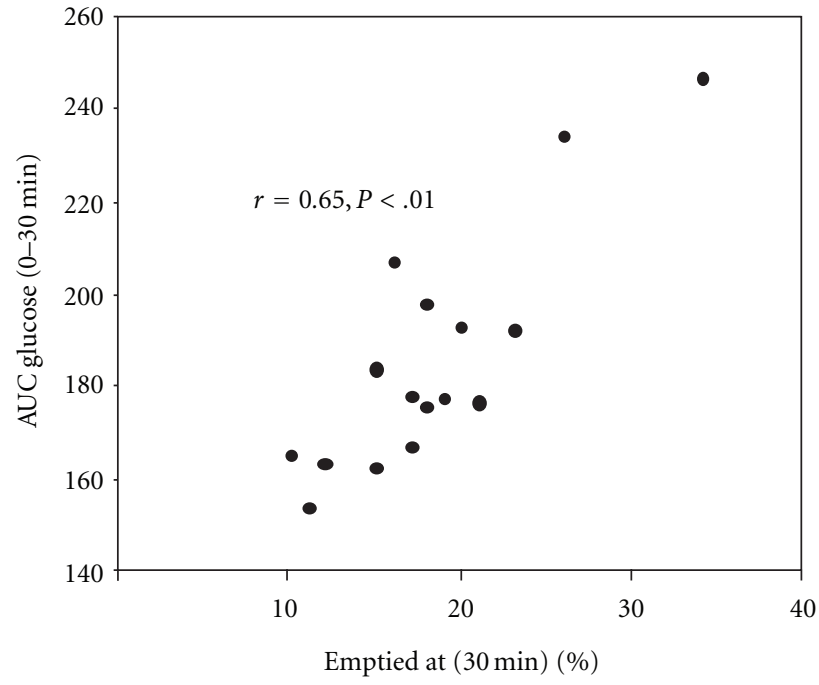

FIGURE 2: Relationship between the area under the plasma glucose concentration curve between 0 and 30 minutes and the retention of the meal in the stomach at 30 minutes $(r=0.65, P<.01)$ (adapted from Horowitz et al. 1993 [45] and used with the permission of the publisher).

of gastric emptying. Even changes within the physiological postprandial blood glucose range (i.e., $4 \mathrm{mmol} / \mathrm{L}$ versus $8 \mathrm{mmol} / \mathrm{L}$ ) affect gastric emptying in healthy as well as uncomplicated type 1 diabetic patients [62]. The slowing of gastric emptying by acute hyperglycaemia reflects the stimulation of pyloric motility $[62,63]$, suppression of antral motility [64], and reduction in proximal gastric tone [65]. Acute hyperglycaemia also attenuates the ability of erythromycin [66], and probably other prokinetic drugs, to accelerate gastric emptying. In contrast to the effect of hyperglycaemia, insulin-induced hypoglycaemia accelerates gastric emptying substantially, probably representing a counterregulatory mechanism [67].

\section{Effects on Gastric Motility}

It has been well established that GLP-1 slows gastric emptying. The following section reviews the effects of GLP- 1 and incretin-based therapies on gastric motility.

4.1. Exogenous GLP-1. Exogenous GLP-1 slows gastric emptying in healthy $[16,19,68]$, obese [69], type 2 diabetic [12], and critically ill subjects [70]. Infusion of GLP-1 slows gastric emptying of both solid and liquid components of a meal and alters intragastric meal distribution so that a greater proportion of the meal is retained in the distal stomach [19] (Figure 3). Even at "low" doses $(0.3 \mathrm{pmol} / \mathrm{kg} /$ minutes, designed to reflect "physiological" postprandial GLP-1 plasma concentrations) intravenous adminutesistration of GLP-1 profoundly slows gastric emptying in a substantial proportion of healthy subjects into the "gastroparetic" range [19]. In both healthy subjects $[16,19,71]$ and type 2 diabetic patients [12], the effect of exogenous GLP-1 on gastric emptying appears to be dose-related. Furthermore, 

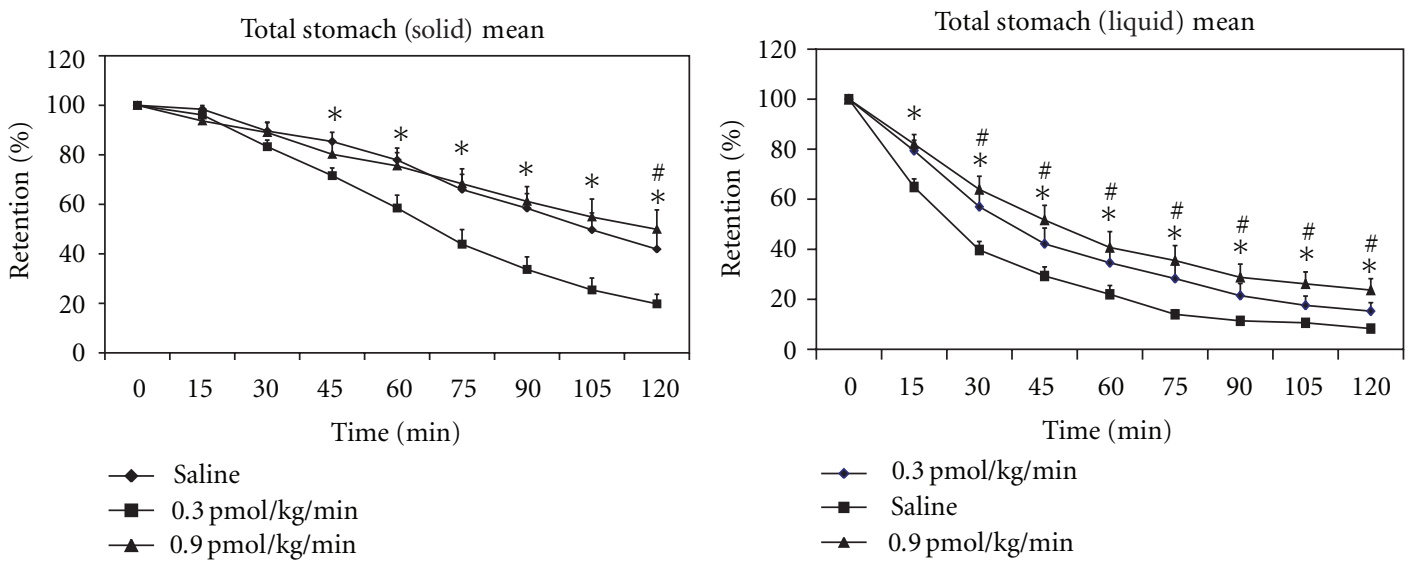

(a)
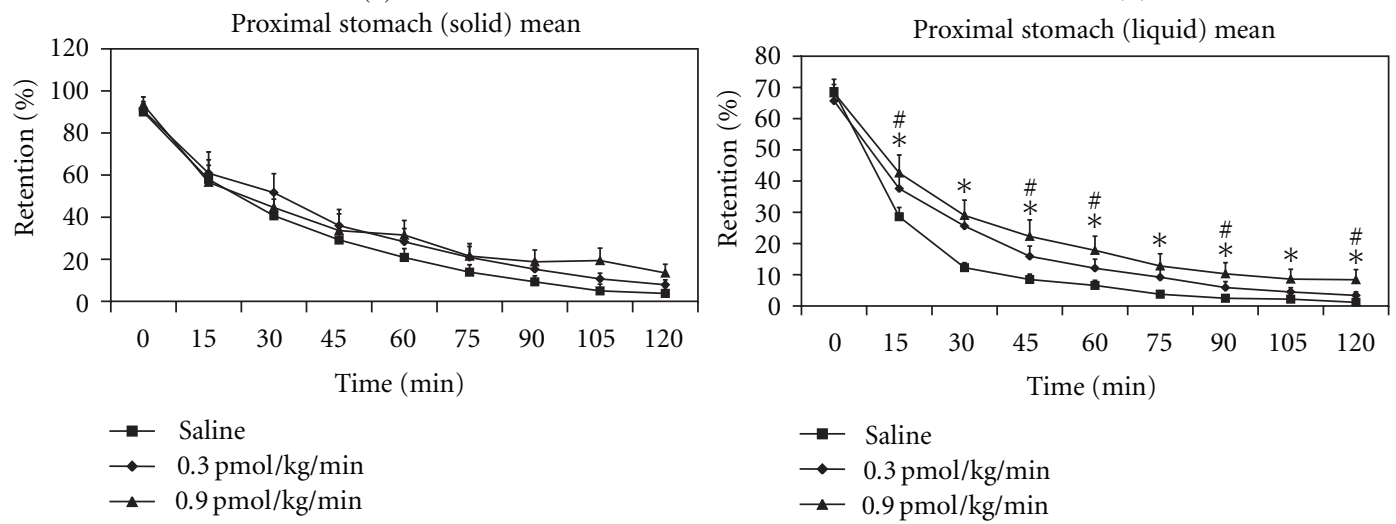

(b)

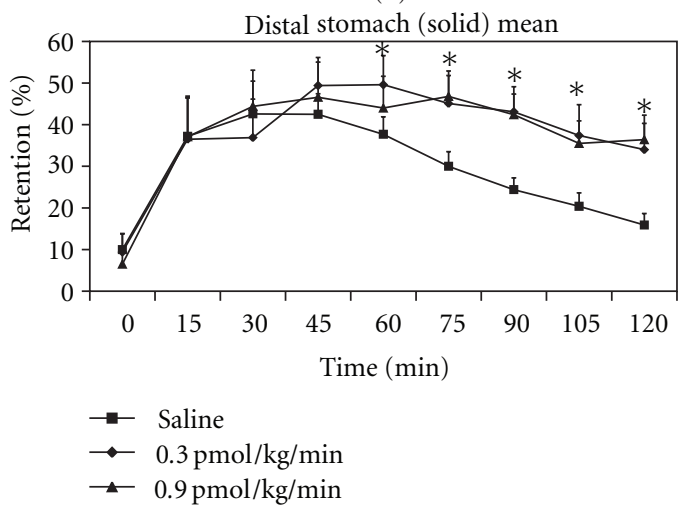

(c)

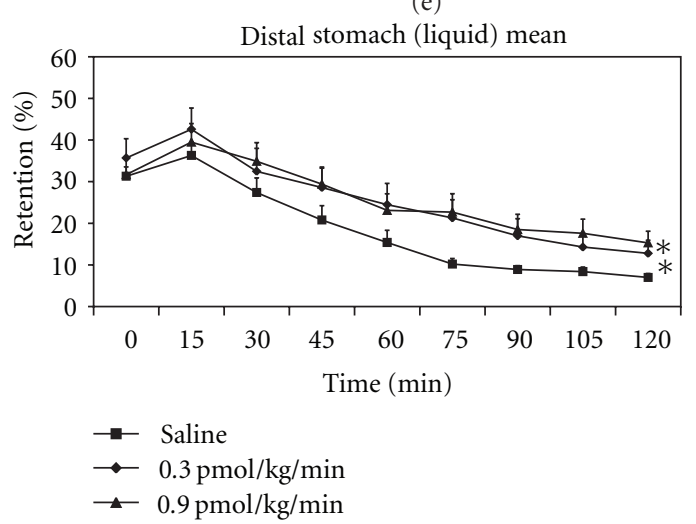

(f)

FIGURE 3: Gastric emptying curves for the solid and liquid components of a meal for the total, proximal, and distal stomach during IV infusion of GLP-1 at 0.3 and $0.9 \mathrm{pmol} / \mathrm{kg} /$ minutes, or $0.9 \%$ saline, in 10 healthy humans. Data are means \pm SEM. ${ }^{*}$ GLP- 10.3 and 0.9 versus saline: $P<.05$; ${ }^{~ G L P-1} 0.9$ versus GLP-1 0.3: $P<.05$ (adapted from Little et al. 2006 [19] and used with permission from the publisher).

an inverse relationship between the early postprandial rise in blood glucose and the rate of gastric emptying, following infusion of exogenous GLP-1, indicates the importance of the gastric motor actions of GLP-1 in its glucose-lowering effect [19]. As would be predicted by the slowing of gastric emptying, exogenous GLP-1 relaxes the proximal stomach in a dose-dependent manner [72], reduces antral and duodenal motility, and increases pyloric tone in both the fasted and the fed states [71].
4.2. Endogenous GLP-1. While a number of studies have employed infusions of exogenous GLP-1 at "low" rates, designed to reflect physiological postprandial GLP-1 concentrations, a more valid approach to assess the role of endogenous GLP-1 is the use of a specific GLP-1 antagonist such as exendin (9-39) amide. It appears that endogenous GLP1 has a modest effect to slow gastric emptying and thereby delay carbohydrate absorption, given a sufficient caloric load [73], by mechanisms that include antral inhibition and 
stimulation of pyloric motility [34]. Three other studies employing exendin (9-39) failed to show an effect of endogenous GLP-1 on gastric emptying [86-88], but this is likely to reflect methodological differences, including the use of a suboptimal technique (plasma D-xylose) for measuring gastric emptying in one study [87]. Furthermore, in one of these studies [88] although no difference in gastric emptying was observed, exendin 9-39 did change the intragastric distribution of the meal, supporting the role of endogenous GLP-1 in regulating gastric motility.

4.3. GLP-1-Based Therapies. The insulinotropic property of GIP is markedly diminutesished in type 2 diabetic patients [89-91], probably in part as an effect of hyperglycaemia. On the other hand, GLP-1 retains its properties (at supraphysiological doses) in type 2 diabetic patients with potent effects on gastric motility and postprandial glycaemic control [12]. Consequently, this hormone has been an important target for the pharmaceutical industry in the treatment of diabetes [12, 81, 92]. This has stimulated the development of synthetic GLP-1 analogues, which are resistant to rapid degradation, and inhibitors of the enzyme DPP-4 (which boost concentrations of the active fraction of endogenous GLP-1). Both classes of drugs are now used widely in the management of type 2 diabetes.

4.3.1. GLP-1 Receptor Agonists. There are a number of GLP1 receptor agonists on the market or in development. Of the established agents, exenatide and liraglutide, the former has been best studied in regards to motor effects. It appears that an important mechanism contributing to the action of exenatide, in reducing postprandial glycaemia, is by slowing gastric emptying $[81,93]$. Exenatide, derived from the saliva of the Gila monster Heloderma suspectum, has been shown to induce a dose-dependent deceleration of gastric emptying in healthy subjects [80] and type 2 diabetic patients [82, 94]. Exenatide slows gastric emptying of both solid and liquid components of a meal, irrespective of the presence of established autonomic neuropathy [81]. However, in both type 2 diabetic patients [81] and patients with critical illness [70], the effects of GLP-1 or incretin-based therapies appear to be dependent on the prior rate of gastric emptying, so that there is little further slowing in those with delayed emptying at baseline. The relevance of this for selecting the most appropriate patients to be treated with exenatide and other GLP-1 agonists remains to be clarified, but it is clearly an important issue for further study. While animal studies with long acting exenatide (LAR exenatide) have failed to show evidence of tachyphylaxis (i.e., reduction in pharmacological response over time) [95], a recent trial in type 2 diabetic patients indicated that gastric emptying may be more strongly slowed by twice daily exenatide than once weekly LAR exenatide [96], suggesting that continuous GLP1 exposure could result in a diminutesution of pharmacological response, potentially reflecting changes in receptor activation and/or changes in vagal function.

The major adverse effects of exenatide and liraglutide are nausea and vomiting. While these could relate to its effects on gastric motor function, and antral distension in particular $[35,36,97]$, the occurrence of adverse effects seems not to relate closely to the delay in gastric emptying $[81,96]$, and it is possible that central mechanisms are important. The effects on gastric emptying have not been comprehensively established for incretin-based therapies other than exenatide, but liraglutide also slows gastric emptying - the magnitude of which is uncertain $[83,84]$. Evaluation of this aspect of drug action represents an important research priority for these agents.

4.3.2. Dipeptidyl Peptidase-4 Inhibitors. Dipeptidyl peptidase-4 inhibitors, including sitagliptin and vildagliptin, result in an increase in circulating active GLP-1 concentrations [27, 98] but appear to have, at most, a modest effect on gastric emptying [27]. Some deceleration in gastric emptying was observed in a study of obese insulin resistant monkeys treated with vildagliptin [85], but human studies published to date have not demonstrated an effect of DPP4 inhibitors on the rate of gastric emptying [82, 99, 100], possibly because the elevation in active GLP-1 concentrations is relatively modest. It should be noted that upper gastrointestinal adverse effects such as nausea and vomiting are less commonly encountered with DPP-4 inhibitors than with GLP-1 receptor agonists, and the relative lack of effects of the former on gastric emptying could well be relevant in this regard.

\section{Effects on Small Intestinal Motility}

The effects of GLP-1 on small intestinal motility have not been extensively studied. Exogenous, intravenous GLP-1 has been shown to inhibit murine fasted and fed small bowel motility in a dose-dependent manner and appears to have an additive effect when combined with intravenous GLP-2 in the fasted state [74]. Exendin (9-39) blocks the inhibition of murine small intestinal motility induced by intraduodenal infusion of peptone [75]. Suppression of fasting small intestinal motility by exogenous GLP-1 is also evident in healthy humans and those with irritable bowel syndrome, manifested by a reduction in the frequency of MMCs in a dose-dependent manner [76]. Indeed, the GLP-1 analogue, ROSE-010, has been reported to be more effective than placebo at relieving abdominutesal pain in irritable bowel syndrome patients [101]. None of the human studies have hitherto evaluated the effects of GLP-1 or its analogues on postprandial small intestinal motility, but this could represent an additional mode of glucose-lowering by these agents, given that pharmacological inhibition of small intestinal flow events has been shown to reduce the rate of small intestinal glucose absorption in healthy humans [102].

\section{Effects on Colonic Motility}

Only a handful of animal studies have specifically evaluated the effects of GLP-1 (exogenous or endogenous) on colonic motility. Adminutesistration of intra-cerebroventricular GLP-1 was reported to increase rat fecal pellet output and 
TABLE 1: Summary of motor effects of GLP-1 and incretin-based therapies on the gastrointestinal tract.

\begin{tabular}{|c|c|c|c|}
\hline & $\begin{array}{c}\text { Gastric motility } \\
\text { (delayed gastric emptying) }\end{array}$ & $\begin{array}{c}\text { Small intestinal motility } \\
\text { (delayed small intestinal transit) }\end{array}$ & $\begin{array}{l}\text { Large intestinal motility } \\
\text { (delayed colonic transit) }\end{array}$ \\
\hline $\begin{array}{l}\text { Endogenous GLP-1 } \\
\text { (physiological dose) }\end{array}$ & One positive study [73] & No studies available & No studies available \\
\hline $\begin{array}{l}\text { Exogenous GLP-1 } \\
\text { (pharmacological dose) }\end{array}$ & $\begin{array}{c}\text { Strong evidence in human } \\
\text { studies; healthy [16], obese [69], } \\
\text { type } 2 \text { diabetic [12], critically ill } \\
{[70]}\end{array}$ & $\begin{array}{l}\text { Positive evidence in animal studies } \\
{[74,75] . \text { Positive effect on fasting }} \\
\text { motility in humans }[76]\end{array}$ & $\begin{array}{c}\text { Positive evidence in animal } \\
\text { studies [77]. Only indirect } \\
\text { evidence in humans }[78,79] .\end{array}$ \\
\hline $\begin{array}{l}\text { GLP-1 receptor agonists } \\
\text { (e.g., exenatide, liraglutide) }\end{array}$ & $\begin{array}{c}\text { Strong evidence with exenatide } \\
\text { (healthy) }[80], \text { (type } 2 \text { diabetes) } \\
{[80-82] . \text { Some evidence with }} \\
\text { liraglutide }[83,84]\end{array}$ & No studies available & No studies available \\
\hline $\begin{array}{l}\text { DPP-4 inhibitors } \\
\text { (e.g., sitagliptin, vildagliptin) }\end{array}$ & $\begin{array}{l}\text { Positive evidence with animal } \\
\text { studies only [85] }\end{array}$ & No studies available & No studies available \\
\hline
\end{tabular}

this was reversed by the GLP-1 receptor antagonist, exendin (9-39) [77]. Evidence for a role for GLP-1 in the regulation of colonic transit in humans has been limited to the reports of GLP-1 secreting tumors and their association with severe constipation and markedly delayed colonic transit $[78,79]$.

\section{Mechanism of Action of GLP-1 and Incretin-Based Therapies on Gut Motility}

The mechanisms by which GLP-1, or incretin-based therapies, exert their motor actions on the gut have not yet been fully elucidated but appear to be complex. A number of studies have indicated involvement of the vagal nerves in mediating some of these effects of GLP-1 [103-105]. Gastric relaxation $[68,105]$ and postprandial gastric accommodation [68], in response to exogenous GLP-1, are mediated by vagal cholinergic pathways; antro-pyloro-duodenal motility apparently is not [103]. Inhibition of fasting small bowel motility in rats by exogenous GLP-1 is mediated via endogenous nitric oxide (NO), while suppression of fed motility is independent of NO [106]. Studies of the rodent duodenum and colon suggest that GLP-1 can decrease excitatory cholinergic neurotransmission in the enteric nervous system via presynaptic GLP-1 receptors, which modulate NO release [107].

Some gastrointestinal motor effects of GLP-1 appear to be centrally mediated-GLP-1 can readily diffuse through the blood-brain barrier $[77,108]$ to gain access to GLP-1 receptors in the circumventricular organs, the subfornical organ, and area postrema [109]; the latter in particular controls vomiting. Albiglutide (or Albugon) is a newer GLP-1 receptor agonist that does not readily diffuse into the area postrema and has a low prevalence of gastrointestinal adverse effects, possibly for this reason $[110,111]$.

\section{Conclusion}

Exploiting the properties of GLP-1 to the fullest for therapeutic purposes will require an in-depth understanding, not only of its incretin effects but also of its impact on gut motility. Although the last decade and a half has seen some important steps in that direction, particularly in understanding the impacts of GLP-1 and incretin-based therapies on gastric emptying, it is clearly a work in progress (Table 1). Further research is needed to gain a better understanding of the actions of GLP-1 and incretin-based therapies on small bowel motility, the extent of the role of endogenous GLP-1 on gut function, and how strongly the motor effects of GLP-1-based therapies are maintained with long-term use. The implications of effects on gastric emptying and small intestinal motility for glycaemic control in diabetes are clinically significant, as the former are often disordered in long-standing diabetes.

\section{References}

[1] W. M. Bayliss and E. H. Starling, "The mechanism of pancreatic secretion," The Journal of Physiology, vol. 28, pp. 325-353, 1902.

[2] B. Moore, E. S. Edie, and J. H. Abram, "On the treatment of Diabetus mellitus by acid extract of Duodenal Mucous Membrane," Biochemical Journal, vol. 1, no. 1, pp. 28-38, 1906.

[3] E. Zunz and J. La Barre, "Contributions à l'étude des variations physiologiques de la sécrétion interne du pancréas: relations entre les sécretions externe et interne du pancréas," Archives Internationales de Physiologie et de Biochimie, vol. 31, pp. 20-44, 1929.

[4] C. Oehme and K. Wimmers, "Wirkung von Duodenalschleimhautextrakten (Secretin) auf den Blutzucker," Zeitschrift für die Gesamte Experimentelle Medizin, vol. 38, no. 1, pp. 1-8, 1923.

[5] L. Takacs, "Versuche mit secretin: I. mitteilung. Blutzuckervermindernde wirkung des secretins bei tierexperimenten," Zeitschrift für die Gesamte Experimentelle Medizin, vol. 57, pp. 527-531, 1927.

[6] H. Elrick, L. Stimmler, C. J. Hlad Jr., and Y. Arai, "Plasma insulin response to oral and intravenous glucose administration," The Journal of Clinical Endocrinology \& Metabolism, vol. 24, pp. 1076-1082, 1964.

[7] N. McIntyre, C. D. Holdsworth, and D. A. Turner, "New interpretation of oral glucose tolerance," The Lancet, vol. 284, no. 7349 , pp. 20-21, 1964. 
[8] W. Creutzfeldt, "The [pre-] history of the incretin concept," Regulatory Peptides, vol. 128, no. 2, pp. 87-91, 2005.

[9] W. Creutzfeldt, “The incretin concept today," Diabetologia, vol. 16, no. 2, pp. 75-85, 1979.

[10] M. Horowitz and M. A. Nauck, "To be or not to be-an incretin or enterogastrone?” Gut, vol. 55, no. 2, pp. 148-150, 2006.

[11] M. A. Nauck, J. J. Holst, B. Willms, and W. Schmiegel, "Glucagon-like peptide 1 (GLP-1) as a new therapeutic approach for type 2-diabetes," Experimental and Clinical Endocrinology and Diabetes, vol. 105, no. 4, pp. 187-195, 1997.

[12] J. J. Meier, B. Gallwitz, S. Salmen et al., "Normalization of glucose concentrations and deceleration of gastric emptying after solid meals during intravenous glucagon-like peptide 1 in patients with type 2 diabetes," The Journal of Clinical Endocrinology \& Metabolism, vol. 88, no. 6, pp. 2719-2725, 2003.

[13] J. J. Meier, G. Kemmeries, J. J. Holst, and M. A. Nauck, "Erythromycin antagonizes the deceleration of gastric emptying by glucagon-like peptide 1 and unmasks its insulinotropic effect in heathy subjects," Diabetes, vol. 54, no. 7, pp. 2212 2218, 2005.

[14] M. A. Nauck, "Is glucagon-like peptide 1 an incretin hormone?” Diabetologia, vol. 42, no. 3, pp. 373-379, 1999.

[15] J. Schirra and B. Goke, "The physiological role of GLP-1 in human: incretin, ileal brake or more?" Regulatory Peptides, vol. 128, no. 2, pp. 109-115, 2005.

[16] M. A. Nauck, U. Niedereichholz, R. Ettler et al., "Glucagonlike peptide 1 inhibition of gastric emptying outweighs its insulinotropic effects in healthy humans," American Journal of Physiology, vol. 273, no. 5, pp. E981-E988, 1997.

[17] J. J. Meier, O. Goetze, J. Anstipp et al., "Gastric inhibitory polypeptide does not inhibit gastric emptying in humans," American Journal of Physiology, vol. 286, no. 4, pp. E621E625, 2004.

[18] T. Edholm, M. Degerblad, P. Gryback et al., "Differential incretin effects of GIP and GLP-1 on gastric emptying, appetite, and insulin-glucose homeostasis," Neurogastroenterology \& Motility, vol. 22, article e1315, pp. 1191-1200, 2010.

[19] T. J. Little, A. N. Pilichiewicz, A. Russo et al., "Effects of intravenous glucagon-like peptide-1 on gastric emptying and intragastric distribution in healthy subjects: relationships with postprandial glycemic and insulinemic responses," The Journal of Clinical Endocrinology \& Metabolism, vol. 91, no. 5, pp. 1916-1923, 2006.

[20] E. Muscelli, A. Mari, A. Casolaro et al., "Separate impact of obesity and glucose tolerance on the incretin effect in normal subjects and type 2 diabetic patients," Diabetes, vol. 57, no. 5, pp. $1340-1348,2008$.

[21] M. B. Toft-Nielsen, S. Madsbad, and J. J. Holst, "Determinants of the effectiveness of glucagon-like peptide-1 in type 2 diabetes," The Journal of Clinical Endocrinology \& Metabolism, vol. 86, no. 8, pp. 3853-3860, 2001.

[22] T. Vilsboll, T. Krarup, C. F. Deacon, S. Madsbad, and J. J. Holst, "Reduced postprandial concentrations of intact biologically active glucagon-like peptide 1 in type 2 diabetic patients," Diabetes, vol. 50, no. 3, pp. 609-613, 2001.

[23] E. Mannucci, F. Tesi, G. Bardini et al., "Effects of metformin on glucagon-like peptide-1 levels in obese patients with and without Type 2 diabetes," Diabetes, Nutrition \& Metabolism, vol. 17, no. 6, pp. 336-342, 2004.
[24] L. Pala, S. Ciani, I. Dicembrini et al., "Relationship between GLP-1 levels and dipeptidyl peptidase-4 activity in different glucose tolerance conditions," Diabetic Medicine, vol. 27, no. 6, pp. 691-695, 2010.

[25] M. J. Theodorakis, O. Carlson, S. Michopoulos et al., "Human duodenal enteroendocrine cells: source of both incretin peptides, GLP-1 and GIP," American Journal of Physiology, vol. 290, no. 3, pp. E550-E559, 2006.

[26] K. Vollmer, J. J. Holst, B. Baller et al., "Predictors of incretin concentrations in subjects with normal, impaired, and diabetic glucose tolerance," Diabetes, vol. 57, pp. 678-687, 2008.

[27] D. J. Drucker and M. A. Nauck, "The incretin system: glucagon-like peptide-1 receptor agonists and dipeptidyl peptidase- 4 inhibitors in type 2 diabetes," The Lancet, vol. 368, no. 9548, pp. 1696-1705, 2006.

[28] M. Horowitz and M. Samsom, Gastrointestinal Function in Diabetes Mellitus, John Wiley \& Sons, 2004.

[29] J. Ma, C. K. Rayner, K. L. Jones, and M. Horowitz, "Diabetic gastroparesis: diagnosis and management," Drugs, vol. 69, no. 8, pp. 971-986, 2009.

[30] M. Thumshirn, M. Camilleri, S. B. Saslow, D. E. Williams, D. D. Burton, and R. B. Hanson, "Gastric accommodation in non-ulcer dyspepsia and the roles of Helicobacter pylori infection and vagal function," Gut, vol. 44, no. 1, pp. 55-64, 1999.

[31] S. D. Kuiken, M. Samsom, M. Camilleri et al., "Development of a test to measure gastric accommodation in humans," American Journal of Physiology, vol. 277, no. 6, pp. G1217G1221, 1999.

[32] E. P. Bouras, S. Delgado-Aros, M. Camilleri et al., "SPECT imaging of the stomach: comparison with barostat, and effects of sex, age, body mass index, and fundoplication. Single photon emission computed tomography," Gut, vol. 51, pp. 781-786, 2002.

[33] I. L. MacGregor, P. Martin, and J. H. Meyer, "Gastric emptying of solid food in normal man and after subtotal gastrectomy and truncal vagotomy with pyloroplasty," Gastroenterology, vol. 72, no. 2, pp. 206-211, 1977.

[34] J. Schirra, M. Nicolaus, R. Roggel et al., "Endogenous glucagon-like peptide 1 controls endocrine pancreatic secretion and antro-pyloro-duodenal motility in humans," Gut, vol. 55, no. 2, pp. 243-251, 2006.

[35] K. L. Jones, S. M. Doran, K. Hveem et al., "Relation between postprandial satiation and antral area in normal subjects," American Journal of Clinical Nutrition, vol. 66, no. 1, pp. 127132, 1997.

[36] K. Sturm, B. Parker, J. Wishart et al., "Energy intake and appetite are related to antral area in healthy young and older subjects," American Journal of Clinical Nutrition, vol. 80, no. 3, pp. 656-667, 2004.

[37] N. W. Read, M. N. Al-Janabi, C. A. Edwards, and D. C. Barber, "Relationship between postprandial motor activity in the human small intestine and the gastrointestinal transit of food," Gastroenterology, vol. 86, no. 4, pp. 721-727, 1984.

[38] T. J. Little, S. Doran, J. H. Meyer et al., "The release of GLP-1 and ghrelin, but not GIP and CCK, by glucose is dependent upon the length of small intestine exposed," American Journal of Physiology, vol. 291, no. 3, pp. E647-E655, 2006.

[39] H. C. Lin, J. E. Doty, T. J. Reedy, and J. H. Meyer, "Inhibition of gastric emptying by sodium oleate depends on length of intestine exposed to nutrient," American Journal of Physiology, vol. 259, no. 6, pp. G1031-G1036, 1990.

[40] J. H. Meyer, M. Hlinka, Y. Tabrizi, N. DiMaso, and H. E. Raybould, "Chemical specificities and intestinal distributions 
of nutrient-driven satiety," American Journal of Physiology, vol. 275, no. 4, pp. R1293-R1307, 1998.

[41] J. H. Meyer, Y. Tabrizi, N. DiMaso, M. Hlinka, and H. E. Raybould, "Length of intestinal contact on nutrient-driven satiety," American Journal of Physiology, vol. 275, no. 4, pp. R1308-R1319, 1998.

[42] I. M. Welch, C. P. Sepple, and N. W. Read, "Comparisons of the effects on satiety and eating behaviour of infusion of lipid into the different regions of the small intestine," Gut, vol. 29, no. 3, pp. 306-311, 1988.

[43] J. J. Holst, "The physiology of glucagon-like peptide 1," Physiological Reviews, vol. 87, no. 4, pp. 1409-1439, 2007.

[44] J. N. Hunt, J. L. Smith, and C. L. Jiang, "Effect of meal volume and energy density on the gastric emptying of carbohydrates," Gastroenterology, vol. 89, no. 6, pp. 13261330, 1985.

[45] M. Horowitz, M. A. Edelbroek, J. M. Wishart, and J. W. Straathof, "Relationship between oral glucose tolerance and gastric emptying in normal healthy subjects," Diabetologia, vol. 36, no. 9, pp. 857-862, 1993.

[46] K. L. Jones, M. Horowitz, B. I. Carney, J. M. Wishart, S. Guha, and L. Green, "Gastric emptying in early noninsulindependent diabetes mellitus," Journal of Nuclear Medicine, vol. 37, no. 10, pp. 1643-1648, 1996.

[47] D. G. O’Donovan, S. Doran, C. Feinle-Bisset et al., "Effect of variations in small intestinal glucose delivery on plasma glucose, insulin, and incretin hormones in healthy subjects and type 2 diabetes," The Journal of Clinical Endocrinology \& Metabolism, vol. 89, no. 7, pp. 3431-3435, 2004.

[48] C. K. Rayner, M. Samsom, K. L. Jones, and M. Horowitz, "Relationships of upper gastrointestinal motor and sensory function with glycemic control," Diabetes Care, vol. 24, no. 2, pp. 371-381, 2001.

[49] A. N. Pilichiewicz, R. Chaikomin, I. M. Brennan et al., "Loaddependent effects of duodenal glucose on glycemia, gastrointestinal hormones, antropyloroduodenal motility, and energy intake in healthy men," American Journal of Physiology, vol. 293, no. 3, pp. E743-E753, 2007.

[50] R. M. Elliott, L. M. Morgan, J. A. Tredger, S. Deacon, J. Wright, and V. Marks, "Glucagon-like peptide-1(7-36)amide and glucose-dependent insulinotropic polypeptide secretion in response to nutrient ingestion in man: acute post-prandial and 24-h secretion patterns," Journal of Endocrinology, vol. 138, no. 1, pp. 159-166, 1993.

[51] S. Katsuma, N. Hatae, T. Yano et al., "Free fatty acids inhibit serum deprivation-induced apoptosis through GPR120 in a murine enteroendocrine cell line STC-1," Journal of Biological Chemistry, vol. 280, no. 20, pp. 19507-19515, 2005.

[52] H. J. Jang, Z. Kokrashvili, M. J. Theodorakis et al., "Gutexpressed gustducin and taste receptors regulate secretion of glucagon-like peptide-1," Proceedings of the National Academy of Sciences of the United States of America, vol. 104, no. 38, pp. 15069-15074, 2007.

[53] J. Ma, J. Chang, H. L. Checklin et al., "Effect of the artificial sweetener, sucralose, on small intestinal glucose absorption in healthy human subjects," British Journal of Nutrition, vol. 104, no. 6, pp. 803-806, 2010.

[54] D. Gentilcore, B. Bryant, J. M. Wishart, H. A. Morris, M. Horowitz, and K. L. Jones, "Acarbose attenuates the hypotensive response to sucrose and slows gastric emptying in the elderly," American Journal of Medicine, vol. 118, no. 11, pp. 1289.e5-1289.e11, 2005.

[55] E. Bonora and M. Muggeo, "Postprandial blood glucose as a risk factor for cardiovascular disease in Type II diabetes: the epidemiological evidence," Diabetologia, vol. 44, no. 12, pp. 2107-2114, 2001.

[56] A. Ceriello, "Postprandial hyperglycemia and diabetes complications: is it time to treat?" Diabetes, vol. 54, no. 1, pp. 1-7, 2005.

[57] C. K. Rayner and M. Horowitz, "Gastrointestinal motility and glycemic control in diabetes: the chicken and the egg revisited?" Journal of Clinical Investigation, vol. 116, no. 2, pp. 299-302, 2006.

[58] H. J. Woerle, M. Albrecht, R. Linke et al., "Importance of changes in gastric emptying for postprandial plasma glucose fluxes in healthy humans," American Journal of Physiology, vol. 294, no. 1, pp. E103-E109, 2008.

[59] S. Gonlachanvit, C. W. Hsu, G. H. Boden et al., "Effect of altering gastric emptying on postprandial plasma glucose concentrations following a physiologic meal in type-II diabetic patients," Digestive Diseases and Sciences, vol. 48, no. 3, pp. 488-497, 2003.

[60] R. J. Fraser, M. Horowitz, A. F. Maddox, P. E. Harding, B. E. Chatterton, and J. Dent, "Hyperglycaemia slows gastric emptying in Type 1 (insulin-dependent) diabetes mellitus," Diabetologia, vol. 33, no. 11, pp. 675-680, 1990.

[61] M. Horowitz, P. E. Harding, A. F. Maddox et al., "Gastric and oesophageal emptying in patients with type 2 (non-insulindependent) diabetes mellitus," Diabetologia, vol. 32, no. 3, pp. 151-159, 1989.

[62] E. Schvarcz, M. Palmer, J. Aman, M. Horowitz, M. Stridsberg, and C. Berne, "Physiological hyperglycemia slows gastric emptying in normal subjects and patients with insulindependent diabetes mellitus," Gastroenterology, vol. 113, no. 1, pp. 60-66, 1997.

[63] R. Fraser, M. Horowitz, and J. Dent, "Hyperglycaemia stimulates pyloric motility in normal subjects," Gut, vol. 32, no. 5, pp. 475-478, 1991.

[64] W. L. Hasler, H. C. Soudah, G. Dulai, and C. Owyang, "Mediation of hyperglycemia-evoked gastric slow-wave dysrhythmias by endogenous prostaglandins," Gastroenterology, vol. 108, no. 3, pp. 727-736, 1995.

[65] G. S. Hebbard, M. Samsom, W. M. Sun, J. Dent, and M. Horowitz, "Hyperglycemia affects proximal gastric motor and sensory function during small intestinal triglyceride infusion," American Journal of Physiology, vol. 271, no. 5, pp. G814-G819, 1996.

[66] K. L. Jones, M. Berry, M. F. Kong, M. A. Kwiatek, M. Samsom, and M. Horowitz, "Hyperglycemia attenuates the gastrokinetic effect of erythromycin and affects the perception of postprandial hunger in normal subjects," Diabetes Care, vol. 22, no. 2, pp. 339-344, 1999.

[67] A. Russo, J. E. Stevens, R. Chen et al., "Insulin-induced hypoglycemia accelerates gastric emptying of solids and liquids in long-standing type 1 diabetes," The Journal of Clinical Endocrinology \& Metabolism, vol. 90, no. 8, pp. 4489-4495, 2005.

[68] S. Delgado-Aros, D. Y. Kim, D. D. Burton et al., "Effect of GLP-1 on gastric volume, emptying, maximum volume ingested, and postprandial symptoms in humans," American Journal of Physiology, vol. 282, no. 3, pp. G424-G431, 2002.

[69] E. Naslund, M. Gutniak, S. Skogar, S. Rossner, and P. M. Hellstrom, "Glucagon-like peptide 1 increases the period of postprandial satiety and slows gastric emptying in obese men," American Journal of Clinical Nutrition, vol. 68, no. 3, pp. 525-530, 1998.

[70] A. M. Deane, M. J. Chapman, R. J. Fraser et al., "Effects of exogenous glucagon-like peptide-1 on gastric emptying 
and glucose absorption in the critically ill: relationship to glycemia," Critical Care Medicine, vol. 38, no. 5, pp. 12611269, 2010.

[71] J. Schirra, P. Houck, U. Wank, R. Arnold, B. Goke, and M. Katschinski, "Effects of glucagon-like peptide-1 (7-36)amide on antro-pyloro-duodenal motility in the interdigestive state and with duodenal lipid perfusion in humans," Gut, vol. 46, no. 5, pp. 622-631, 2000.

[72] J. Schirra, U. Wank, R. Arnold, B. Goke, and M. Katschinski, "Effects of glucagon-like peptide-1 (7-36)amide on motility and sensation of the proximal stomach in humans," Gut, vol. 50, no. 3, pp. 341-348, 2002.

[73] A. M. Deane, N. Q. Nguyen, J. E. Stevens et al., "Endogenous glucagon-like peptide-1 slows gastric emptying in healthy subjects, attenuating postprandial glycemia," The Journal of Clinical Endocrinology \& Metabolism, vol. 95, no. 1, pp. 215$221,2010$.

[74] A. Bozkurt, E. Naslund, J. J. Holst, and P. M. Hellstrom, "GLP-1 and GLP-2 act in concert to inhibit fasted, but not fed, small bowel motility in the rat," Regulatory Peptides, vol. 107, no. 1-3, pp. 129-135, 2002.

[75] M. Giralt and P. Vergara, "Glucagonlike peptide-1 (GLP-1) participation in ileal brake induced by intraluminal peptones in rat," Digestive Diseases and Sciences, vol. 44, no. 2, pp. 322 329, 1999.

[76] P. M. Hellstrom, E. Naslund, T. Edholm et al., "GLP-1 suppresses gastrointestinal motility and inhibits the migrating motor complex in healthy subjects and patients with irritable bowel syndrome," Neurogastroenterology and Motility, vol. 20, no. 6, pp. 649-659, 2008.

[77] M. A. Gulpinar, A. Bozkurt, T. Coskun, N. B. Ulusoy, and B. C. Yegen, "Glucagon-like peptide (GLP-1) is involved in the central modulation of fecal output in rats," American Journal of Physiology, vol. 278, no. 6, pp. G924-G929, 2000.

[78] P. L. Brubaker, D. J. Drucker, S. L. Asa, C. Swallow, M. Redston, and G. R. Greenberg, "Prolonged gastrointestinal transit in a patient with a glucagon-like peptide (GLP)1- and-2-producing neuroendoerine tumor," The Journal of Clinical Endocrinology \& Metabolism, vol. 87, no. 7, pp. 30783083, 2002.

[79] M. M. Byrne, G. P. McGregor, P. Barth, M. Rothmund, B. Goke, and R. Arnold, "Intestinal proliferation and delayed intestinal transit in a patient with a GLP-1-, GLP-2- and PYY-producing neuroendocrine carcinoma," Digestion, vol. 63 , no. 1, pp. 61-68, 2001.

[80] E. Blase, K. Taylor, H. Y. Gao, M. Wintle, and M. Fineman, "Pharmacokinetics of an oral drug (acetaminophen) administered at various times in relation to subcutaneous injection of exenatide (exendin-4) in healthy subjects," Journal of Clinical Pharmacology, vol. 45, no. 5, pp. 570-577, 2005.

[81] H. Linnebjerg, S. Park, P. A. Kothare et al., "Effect of exenatide on gastric emptying and relationship to postprandial glycemia in type 2 diabetes," Regulatory Peptides, vol. 151, no. 1-3, pp. 123-129, 2008.

[82] R. A. DeFronzo, T. Okerson, P. Viswanathan, X. Guan, J. H. Holcombe, and L. MacConell, "Effects of exenatide versus sitagliptin on postprandial glucose, insulin and glucagon secretion, gastric emptying, and caloric intake: a randomized, cross-over study," Current Medical Research and Opinion, vol. 24, no. 10, pp. 2943-2952, 2008.

[83] C. B. Juhl, M. Hollingdal, J. Sturis et al., "Bedtime administration of NN2211, a long-acting GLP-1 derivative, substantially reduces fasting and postprandial glycemia in type 2 diabetes," Diabetes, vol. 51, no. 2, pp. 424-429, 2002.
[84] E. Wajcberg and A. Amarah, "Liraglutide in the management of type 2 diabetes," Journal of Drug Design, Development and Therapy, vol. 4, pp. 279-290, 2010.

[85] B. Dardik, "NVP-LAF237, a dipeptidyl peptidase IV inhibitor, improves glucose tolerance and delays gastric emptying in obese insulin resistant cynomolgus monkeys," Diabetes, vol. 52, supplement 1, abstract 1392-P, p. A322, 2003.

[86] M. Nicolaus, J. Brodl, R. Linke, H. J. Woerle, B. Goke, and J. Schirra, "Endogenous GLP-1 regulates postprandial glycemia in humans: relative contributions of insulin, glucagon, and gastric emptying," The Journal of Clinical Endocrinology \& Metabolism, vol. 96, pp. 229-236, 2011.

[87] M. Salehi, T. P. Vahl, and D. A. D’Alessio, "Regulation of islet hormone release and gastric emptying by endogenous glucagon-like peptide 1 after glucose ingestion," The Journal of Clinical Endocrinology \& Metabolism, vol. 93, no. 12, pp. 4909-4916, 2008.

[88] A. B. Witte, P. Gryback, H. Jacobsson et al., "Involvement of endogenous glucagon-like peptide-1 in regulation of gastric motility and pancreatic endocrine secretion," Scandinavian Journal of Gastroenterology, vol. 46, no. 4, pp. 428-435, 2011.

[89] J. C. Brown, V. Mutt, and R. A. Pederson, "Further purification of a polypeptide demonstrating enterogastrone activity," Journal of Physiology, vol. 209, no. 1, pp. 57-64, 1970.

[90] M. A. Nauck, M. M. Heimesaat, C. Orskov, J. J. Holst, R. Ebert, and W. Creutzfeldt, "Preserved incretin activity of glucagon-like peptide 1 [7-36 amide] but not of synthetic human gastric inhibitory polypeptide in patients with type2 diabetes mellitus," Journal of Clinical Investigation, vol. 91, no. 1, pp. 301-307, 1993.

[91] W. Kim and J. M. Egan, "The role of incretins in glucose homeostasis and diabetes treatment," Pharmacological Reviews, vol. 60, no. 4, pp. 470-512, 2008.

[92] M. A. Nauck, "Incretin-based therapies for type 2 diabetes mellitus: properties, functions, and clinical implications," American Journal of Medicine, vol. 124, pp. S3-S18, 2011.

[93] R. S. Cvetković and G. L. Plosker, "Exenatide: a review of its use in patients with type 2 diabetes mellitus (as an adjunct to metformin and/or a sulfonylurea)," Drugs, vol. 67, no. 6, pp. 935-954, 2007.

[94] O. G. Kolterman, D. D. Kim, L. Shen et al., "Pharmacokinetics, pharmacodynamics, and safety of exenatide in patients with type 2 diabetes mellitus," American Journal of HealthSystem Pharmacy, vol. 62, no. 2, pp. 173-181, 2005.

[95] B. R. Gedulin, P. Smith, K. S. Prickett et al., "Dose-response for glycaemic and metabolic changes 28 days after single injection of long-acting release exenatide in diabetic fatty Zucker rats," Diabetologia, vol. 48, no. 7, pp. 1380-1385, 2005.

[96] D. J. Drucker, J. B. Buse, K. Taylor et al., "Exenatide once weekly versus twice daily for the treatment of type 2 diabetes: a randomised, open-label, non-inferiority study," The Lancet, vol. 372, no. 9645, pp. 1240-1250, 2008.

[97] K. Hveem, K. L. Jones, B. E. Chatterton, and M. Horowitz, "Scintigraphic measurement of gastric emptying and ultrasonographic assessment of antral area: relation to appetite," Gut, vol. 38, no. 6, pp. 816-821, 1996.

[98] A. Mari, W. M. Sallas, Y. L. He et al., "Vildagliptin, a dipeptidyl peptidase-IV inhibitor, improves model-assessed beta-cell function in patients with type 2 diabetes," The Journal of Clinical Endocrinology \& Metabolism, vol. 90, no. 8, pp. 4888-4894, 2005. 
[99] A. Vella, G. Bock, P. D. Giesler et al., "The effect of dipeptidyl peptidase-4 inhibition on gastric volume, satiation and enteroendocrine secretion in type 2 diabetes: a double-blind, placebo-controlled crossover study," Clinical Endocrinology, vol. 69, no. 5, pp. 737-744, 2008.

[100] A. Vella, G. Bock, P. D. Giesler et al., "Effects of dipeptidyl peptidase-4 inhibition on gastrointestinal function, meal appearance, and glucose metabolism in type 2 diabetes," Diabetes, vol. 56, no. 5, pp. 1475-1480, 2007.

[101] P. M. Hellstrom, J. Hein, P. Bytzer, E. Bjornsson, J. Kristensen, and H. Schambye, "Clinical trial: the glucagon-like peptide1 analogue ROSE-010 for management of acute pain in patients with irritable bowel syndrome: a randomized, placebo-controlled, double-blind study," Alimentary Pharmacology and Therapeutics, vol. 29, no. 2, pp. 198-206, 2009.

[102] R. Chaikomin, K. L. Wu, S. Doran et al., "Concurrent duodenal manometric and impedance recording to evaluate the effects of hyoscine on motility and flow events, glucose absorption, and incretin release," American Journal of Physiology, vol. 292, no. 4, pp. G1099-G1104, 2007.

[103] J. Schirra, M. Nicolaus, H. J. Woerle, C. Struckmeier, M. Katschinski, and B. Goke, "GLP-1 regulates gastroduodenal motility involving cholinergic pathways," Neurogastroenterology and Motility, vol. 21, no. 6, pp. 609-e22, 2009.

[104] J. Schirra, P. Leicht, P. Hildebrand et al., "Mechanisms of the antidiabetic action of subcutaneous glucagon-like peptide1(7-36)amide in non-insulin dependent diabetes mellitus," Journal of Endocrinology, vol. 156, no. 1, pp. 177-186, 1998.

[105] S. Delgado-Aros, A. Vella, M. Camilleri et al., "Effects of glucagon-like peptide-1 and feeding on gastric volumes in diabetes mellitus with cardio-vagal dysfunction," Neurogastroenterology and Motility, vol. 15, no. 4, pp. 435-443, 2003.

[106] T. Tolessa, M. Gutniak, J. J. Holst, S. Efendic, and P. M. Hellstrom, "Inhibitory effect of glucagon-like peptide-1 on small bowel motility: fasting but not fed motility inhibited via nitric oxide independently of insulin and somatostatin," Journal of Clinical Investigation, vol. 102, no. 4, pp. 764-774, 1998.

[107] A. Amato, L. Cinci, A. Rotondo et al., "Peripheral motor action of glucagon-like peptide-1 through enteric neuronal receptors," Neurogastroenterology and Motility, vol. 22, no. 6, pp. 664-e203, 2010.

[108] A. J. Kastin, V. Akerstrom, and W. Pan, "Interactions of glucagon-like peptide-1 (GLP-1) with the blood-brain barrier," Journal of Molecular Neuroscience, vol. 18, no. 1-2, pp. 7-14, 2002.

[109] C. Orskov, S. S. Poulsen, M. Moller, and J. J. Holst, "Glucagon-like peptide I receptors in the subfornical organ and the area postrema are accessible to circulating glucagonlike peptide I," Diabetes, vol. 45, no. 6, pp. 832-835, 1996.

[110] E. L. St Onge and S. A. Miller, "Albiglutide: a new GLP-1 analog for the treatment of type 2 diabetes," Expert Opinion on Biological Therapy, vol. 10, no. 5, pp. 801-806, 2010.

[111] L. L. Baggio, Q. Huang, T. J. Brown, and D. J. Drucker, "A recombinant human glucagon-like peptide (GLP)-1albumin protein (Albugon) mimics peptidergic activation of GLP-1 receptor-dependent pathways coupled with satiety, gastrointestinal motility, and glucose homeostasis," Diabetes, vol. 53, no. 9, pp. 2492-2500, 2004. 


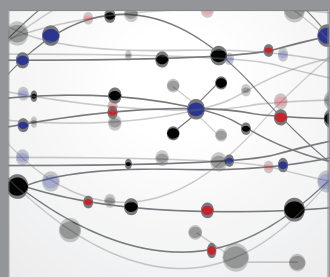

The Scientific World Journal
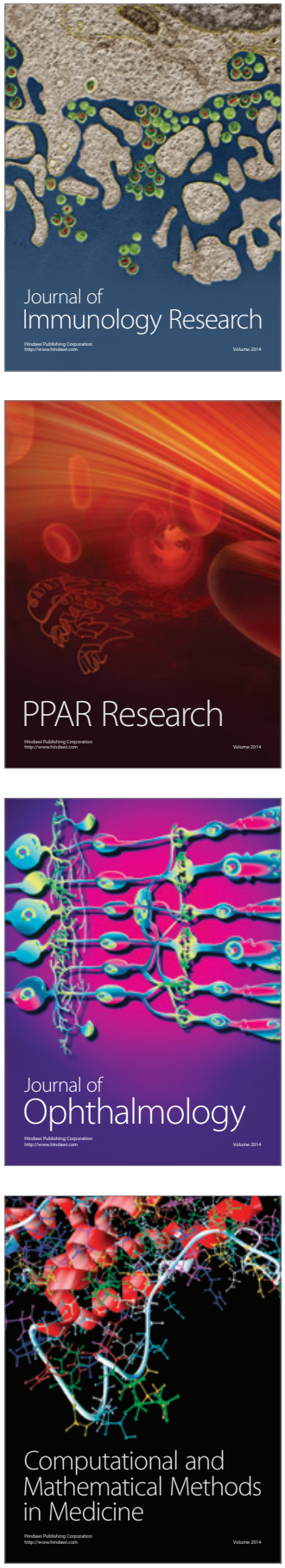

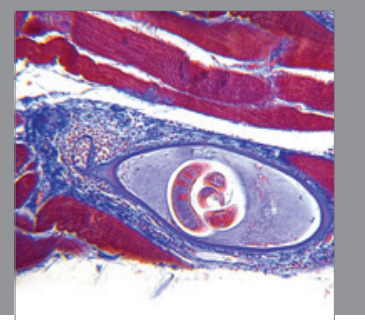

Gastroenterology

Research and Practice
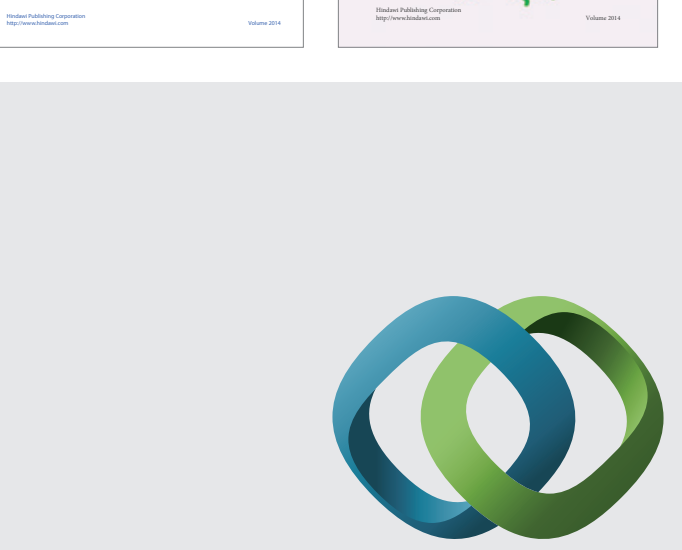

\section{Hindawi}

Submit your manuscripts at

http://www.hindawi.com
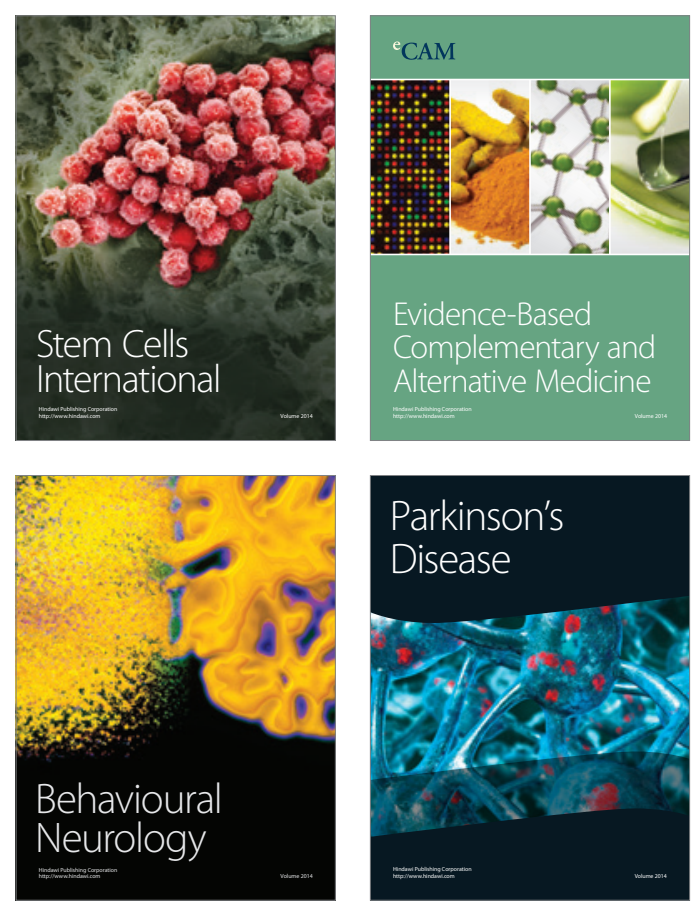

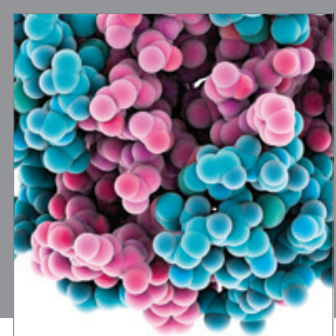

Journal of
Diabetes Research

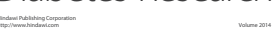

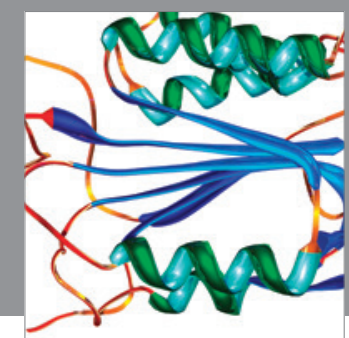

Disease Markers
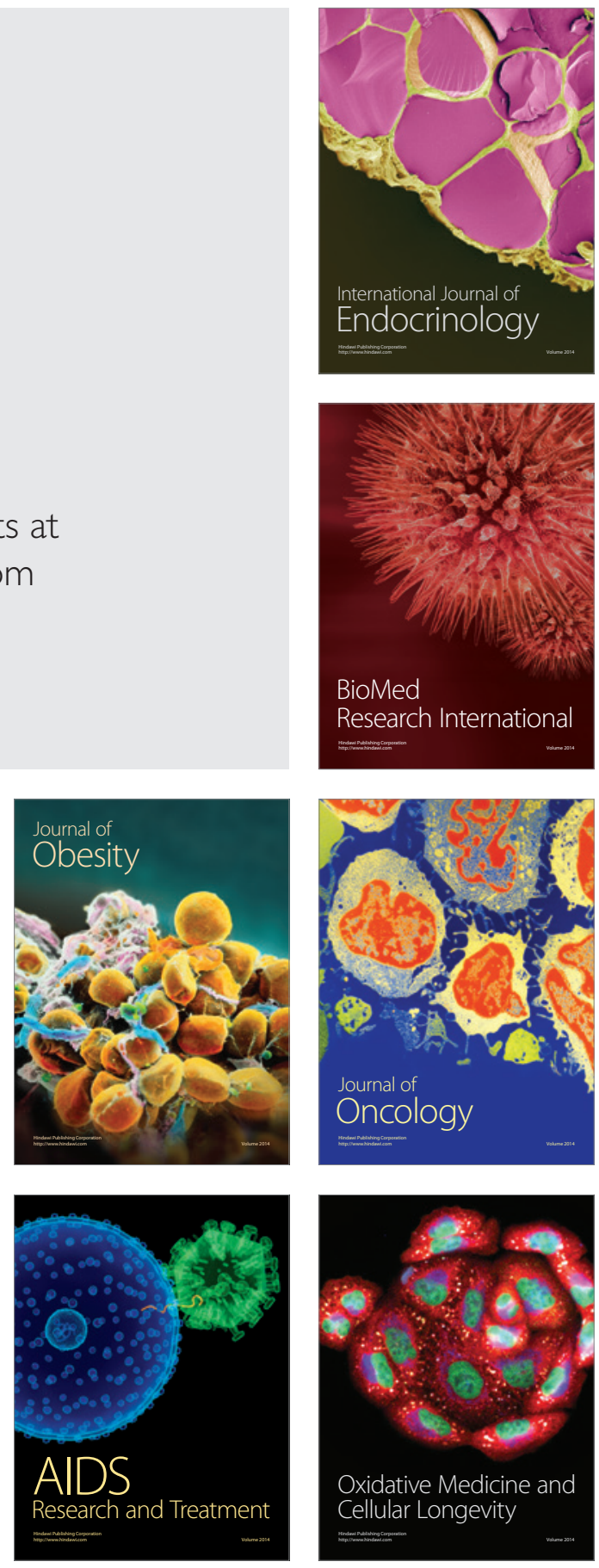